Methods for Field Studies of the Effects of Military Smokes, Obscurants, and Riotcontrol Agents on Threatened and Endangered Species

Volume 1: Background, Overview, Issues, and Recommendations

Thomas Smith

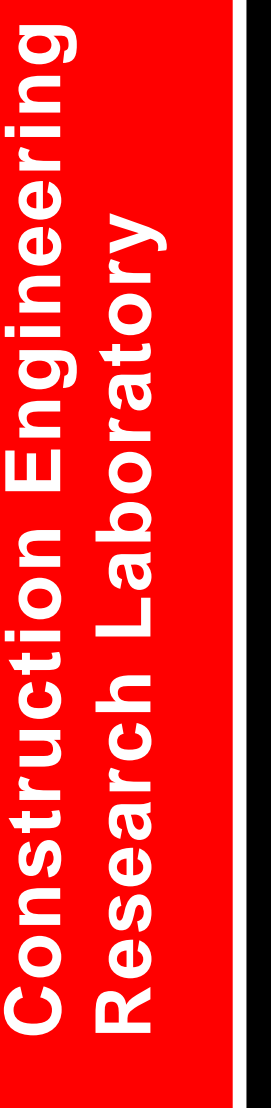




\section{Methods for Field Studies of the Effects of Military Smokes, Obscurants, and Riot-control Agents on Threatened and Endangered Species: Volume 1: Background, Overview, Issues, and Recommendations}

Thomas Smith

Construction Engineering Research Laboratory

PO Box 9005

Champaign, IL 61826-9005

Final Report

Approved for public release; distribution is unlimited.

Prepared for SERDP

Arlington, VA 22203-1821

Under

Work Unit CS-766 
ABSTRACT: Smokes, obscurants, and riot-control agents constitute a diverse group of chemical compounds that are released into the environment during training exercises. Concern has been expressed over the use of these compounds and how they may affect threatened and endangered (T\&E) species that reside on military installations.

This report (Volume 1 in a series) contains an overview of studies and investigations on the effects and impacts of military smokes, obscurants, and riot-control agents on T\&E species. It also discusses the primary laws and regulations of interest and importance to the military services when using these agents on training lands.

Volume 2 (CERL TR 97/140, September 1997) reviews methods for assessing ecological risks. Volume 3 (ERDC/CERL TR-01-59, September 2001) discusses strategies for developing a statistically sound approach to assessing the effects of military smokes, obscurants, and riot-control agents. Volume 4 (USACERL Technical Report 99/56, July 1999) examines chemical analytical methods for isolating and detecting the components of smokes, obscurants, and riot-control agents from environmental media.

DISCLAIMER: The contents of this report are not to be used for advertising, publication, or promotional purposes.

Citation of trade names does not constitute an official endorsement or approval of the use of such commercial products.

All product names and trademarks cited are the property of their respective owners. The findings of this report are not to be construed as an official Department of the Army position unless so designated by other authorized documents.

DESTROY THIS REPORT WHEN IT IS NO LONGER NEEDED. DO NOT RETURN IT TO THE ORIGINATOR. 


\section{Contents}

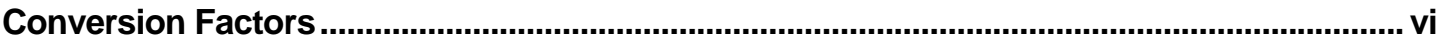

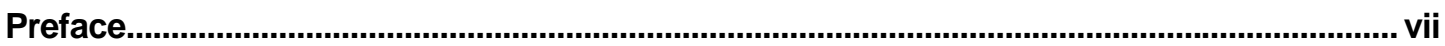

1 Introduction

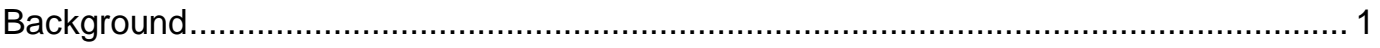

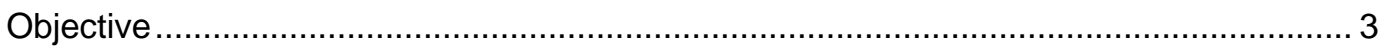

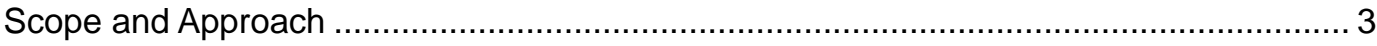

Mode of Technology Transfer ................................................................................. 5

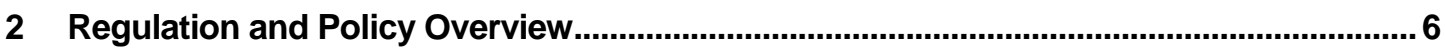

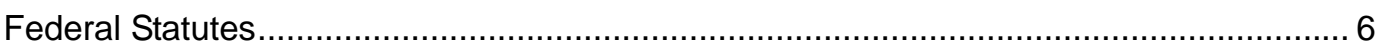

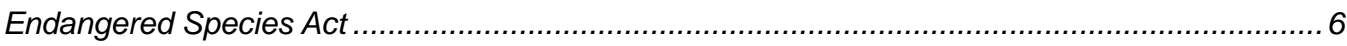

Sikes Act

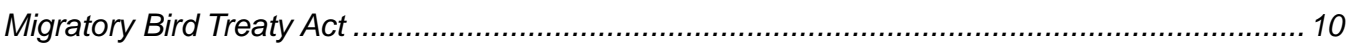

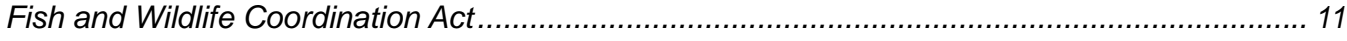

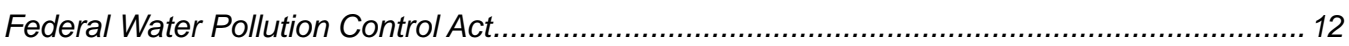

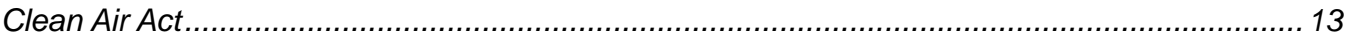

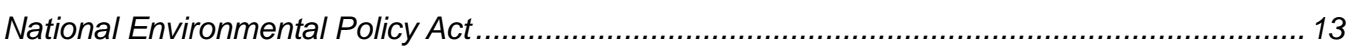

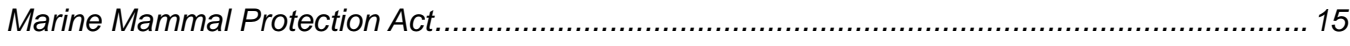

Magnusen-Stevens Fishery Conservation and Management Act ......................................... 15

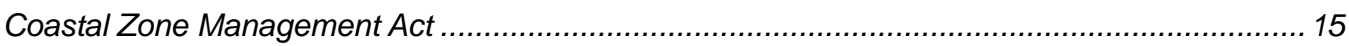

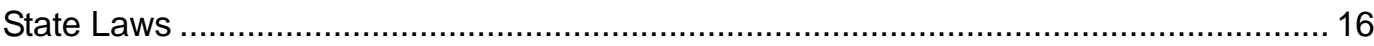

Department of Defense and Other Regulations …................................................. 17

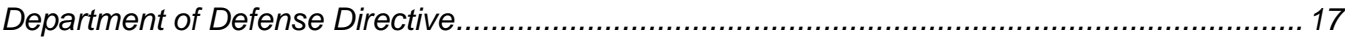

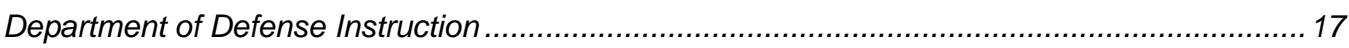

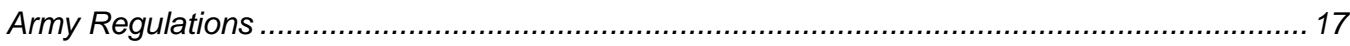

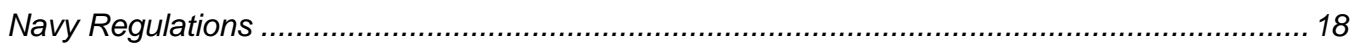

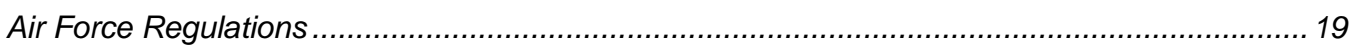

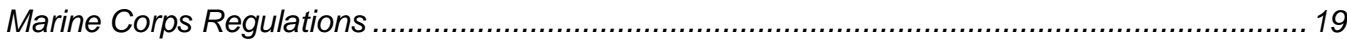

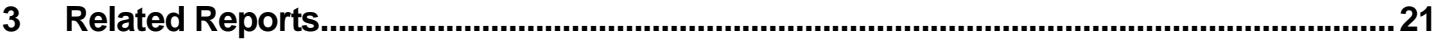

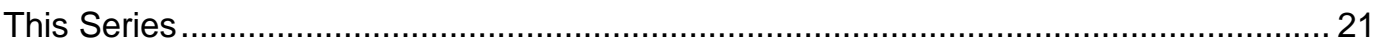

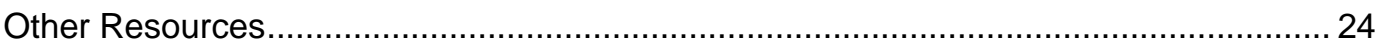

Relevant Military Smoke, Obscurant, and Riot-Control Agent Studies............................ 26 
4 Issues

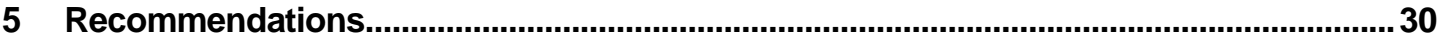

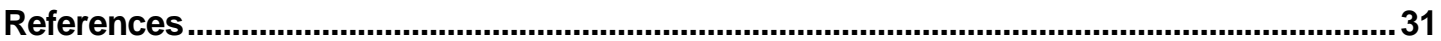

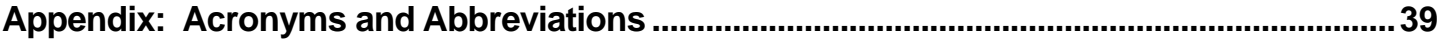

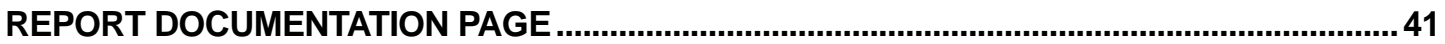




\section{Conversion Factors}

Non-SI* units of measurement used in this report can be converted to SI units as follows:

\begin{tabular}{|c|c|c|}
\hline Multiply & By & To Obtain \\
\hline acres & $4,046.873$ & square meters \\
\hline cubic feet & 0.02831685 & cubic meters \\
\hline cubic inches & 0.00001638706 & cubic meters \\
\hline degrees (angle) & 0.01745329 & radians \\
\hline degrees Fahrenheit & $(5 / 9) \times\left({ }^{\circ} \mathrm{F}-32\right)$ & degrees Celsius \\
\hline degrees Fahrenheit & $(5 / 9) \times\left({ }^{\circ} \mathrm{F}-32\right)+273.15$ & kelvins \\
\hline feet & 0.3048 & meters \\
\hline gallons (U.S. liquid) & 0.003785412 & cubic meters \\
\hline horsepower (550 ft-lb force per second) & 745.6999 & watts \\
\hline inches & 0.0254 & meters \\
\hline kips per square foot & 47.88026 & kilopascals \\
\hline kips per square inch & 6.894757 & megapascals \\
\hline miles (U.S. statute) & 1.609347 & kilometers \\
\hline pounds (force) & 4.448222 & newtons \\
\hline pounds (force) per square inch & 0.006894757 & megapascals \\
\hline pounds (mass) & 0.4535924 & kilograms \\
\hline square feet & 0.09290304 & square meters \\
\hline square miles & $2,589,998$ & square meters \\
\hline tons (force) & $8,896.443$ & newtons \\
\hline tons ( 2,000 pounds, mass) & 907.1847 & kilograms \\
\hline yards & 0.9144 & meters \\
\hline
\end{tabular}

\footnotetext{
*Système International d'Unités ("International System of Measurement"), commonly known as the "metric system."
} 


\section{Preface}

This study was conducted for the Strategic Environmental Research and Development Program (SERDP) under project number CS-766, "Identification, Assessment, and Mitigation of Impacts of Military Related Chemicals and Pollutants on TES," and project number CS-507, "Threatened and Endangered, and Sensitive Resources: Impact of Smokes and Obscurants on TES." Congress established SERDP through Public Law 101-510 on 5 November 1990 (10 U.S.C. 2901-29040). SERDP is a joint multiagency (Department of Defense, Department of Energy, and Environmental Protection Agency) effort to support environmental quality research, development, demonstration, and application programs. The technical monitor at the beginning of this work was Dr. Femi A. Ayorinde, SERDP Cleanup and Conservation Program Manager, followed by Dr. Robert Holst, SERDP Compliance and Conservation Program Manager. The Executive Director of SERDP is Mr. Bradley P. Smith.

The work was completed through the Ecological Processes Branch (CN-N) of the Installations Division (CN), Construction Engineering Research Laboratory (CERL). The CERL Principal Investigator was Mr. Thomas Smith. Ms. Patricia M. Kirby coordinated preparation of the report. The technical editor was Gloria J. Wienke, Information Technology Laboratory. Dr. Hal E. Balbach was the Threatened and Endangered Species Research Project Leader. Mr. Stephen E. Hodapp is Chief, CEERD-CN-N, and Dr. John T. Bandy is Chief, CEERD-CN. The associated Technical Director was Dr. William D. Severinghaus, CEERDCV-T. The Director of CERL is Dr. Alan W. Moore.

CERL is an element of the U.S. Army Engineer Research and Development Center (ERDC), U.S. Army Corps of Engineers. The Commander and Executive Director of ERDC is COL James R. Rowan and the Director of ERDC is Dr. James R. Houston. 


\section{Introduction}

\section{Background}

The Department of Defense (DoD) is the Federal executive agency charged with the overall defense from any and all foreign military threats to this country. This responsibility includes the need to develop, manage, and maintain military capability, personnel, and installations-in short, a military force to be able to meet and respond to foreign national security threats. Implicit with this responsibility is the need to maintain military personnel in a state of readiness by conducting training exercises that fully simulate potential battlefield conditions.

The DoD, through the military services (Army, Navy, Marine Corps, Air Force) and performance of their respective defense missions, controls and manages approximately 25 million acres of land throughout the United States and its possessions. The Army alone manages the land and natural resources on more than 11 million acres. The Army and the other military services must manage and maintain these lands and resources with a realization and a sense of stewardship not only because of their national security importance as military laboratory and training areas, but also because of their intrinsic value, ecological importance, and certainly their status as public resources for the support, use, and enjoyment of present and future generations.

Land and ecosystem management principles and techniques can be considered universal in that ecosystem functioning does not recognize land ownership distinctions. For example, fire is a natural component of climax and seral stage vegetation in many regions. This biologic fact is not changed because of differing land ownership. In that sense the ecologic management of military lands follows the same biological rules that are applicable to nonmilitary lands.

In some cases, military training and testing, in part because of its inherently intense nature, can place severe stresses on landscapes and ecosystems. Some land and ecosystem disturbance caused by military activities can have similarities and parallels with disturbance resulting from nonmilitary activities. In a gross and general way, disturbances caused by armored vehicle maneuvers for example, can be compared to construction and agricultural activities involving similarly massive equipment. However, other disturbances can be considered 
military specific. For example, the testing and training deployment of weapons and weapons support and related systems does not have an obvious nonmilitary counterpart activity. A specific example of this disturbance is that caused by the training and testing use of obscurants and other smokes. In battlefield situations these smokes are typically used to obscure or hide troop and equipment movements, for signaling, to mark specific sites or locations, or for specialized applications such as obscuring infrared wavelengths.

The principal purpose of DoD lands and waters is to support military mission related activities, including realistic military training and testing. Moreover, the DoD and component defense departments (e.g., Department of the Army, Department of the Navy, Department of the Air Force), as Federal government agencies, must be cognizant of and comply with mandates, regulations, and laws promulgated by the Congress and the various jurisdictions of and within the separate states. DoD lands and waters are required to be ecologically and otherwise sustained for the citizens of the nation as well as in conformance with public law (e.g., Sikes Act). The promotion and maintenance of biological integrity, biodiversity, and biologically or geographically significant or sensitive natural resources and species is implicitly and explicitly required on DoD lands (Sikes Act; Endangered Species Act; Conservation and Cultural Activities on Military Lands, 10 U.S. Code [USC] 2694). Threatened and endangered species are of particular concern, interest, and value to the people of the nation. DoD policy is to promote the furtherance of the conservation of threatened and endangered species (DoD Directive [DoDD] 1989, 1996).

To address the need to manage DoD lands and waters to protect, conserve, and maintain threatened and endangered species and other biological resources in the face of multiple and sometimes conflicting uses, it is important to employ sound judgments and methodologies to evaluate the effects of military activities on those resources. Obscurants and other smokes and aerosol agents can be considered potential environmental or ecological stressors. By definition, ecological stressors produce a strain or tension on a system. The magnitude of, the reaction to, and the results of ecological stressors on biological systems, component species, or individual organisms varies with the stressor, time, and space. Evaluating the effects of obscurant and other smokes and riot-control agents on biological resources and in particular threatened and endangered species will provide help and understanding to: (a) maintain the availability of military training and testing lands; (b) maintain and maximize training realism; (c) develop strategies to maximize use and benefits of DoD lands; (d) provide DoD and other biologists and natural resources managers with insights to the health and status of threatened and endangered species; and (e) aid and support the conser- 
vation and recovery of those species and the biological and ecological systems that support them.

\section{Objective}

The objective of this report is to provide guidance and recommendations regarding the conservation and management of threatened and endangered species and their habitats on military lands and waters, in the context of the use, application, and management of military smokes, obscurants, and riot-control agents in training and testing protocols in biological and ecological systems (i.e., natural environments and simulated battlefield conditions).

This report also provides an overview and summary of Congressionally directed authorities, requirements, and actions related to threatened and endangered species and other species of concern that need to be considered as related to the use of military smokes, obscurants, and riot-control agents. While this report, and the others in this series (as described in Scope and Approach), focus on the background, methods, and approaches for the study and evaluation of the effects and impacts of military smokes, obscurants and riot-control agents on threatened and endangered species, the information contained herein is appropriately applicable to other species as well.

\section{Scope and Approach}

In this report, the regulatory authority and obligations as well as the military policy relevant to threatened and endangered species are reviewed in the context of military smokes, obscurants, and riot-control agents. This is Volume 1 in a report series, titled Methods for Field Studies of Effects of Military Smokes, Obscurants, and Riot-control Agents on Threatened and Endangered Species. The other volumes in this report series include detailed reports on and are subtitled:

- Volume 2: Methods for Assessing Ecological Risks (1997);

- Volume 3: Statistical Methods (2001); and

- Volume 4: Chemical Analytical Methods and unattached Appendices (1999).

In total, this report series is intended to be an aid and a tool to assist biologists, land managers, and military trainers to plan, design, and conduct scientifically valid and relevant studies and investigations on the effects and impacts of military smokes, obscurants, and riot-control agents on threatened and endangered species. The series will also help in the planning and implementation of ecologically considerate military smoke, obscurant, and riot-control agent training and 
testing exercises. In large part because the major user, at least in terms of military mission responsibilities, of military smokes and obscurants is the Army, this report, and this series of reports, tends to emphasize Army related applications and considerations. However, since the topic area is one of interest to all of the military services, an effort has been made to make the entire series useful and relevant to all the military service branches. Concurrently, while the emphasis is on threatened and endangered species, as indicated previously, the approach and information provided is relevant and applicable to all other species as well.

These reports are written and intended for a primary audience of military biologists and natural resources managers, and military trainers and training planners. However, it is hoped that these reports will be useful to other wildlife biologists, natural resources managers, and personnel with responsibilities or interest in threatened and endangered species. In addition, they are applicable as resources to contractors or consultants who may prepare permit applications, environmental assessments, biological assessments, or other documents. To the extent that these reports pull together and summarize existing and developing methodologies, theories, and supporting literature, they provide and present elements of basic environmental or biological science. The information, concepts, and techniques are presented in a manner that should be understandable to a reader with a good background and training in biology and ecology. It is hoped that these reports will stimulate and encourage further investigation. Toward that end, these reports should be used and viewed as a starting point for those with a need for further and/or more detailed information on military smoke, obscurant, and riot-control agent investigation, and military installation and activity use.

In this report, laws, rules, directives, instructions, and regulations are cited frequently and directly quoted. This report is not intended to provide a comprehensive, detailed explanation of the various Federal and other laws that may be related to threatened and endangered and other species considerations on military installations. Rather, references to Federal and State laws and regulations are provided to assist the user in becoming aware of and understanding the various authorities that exist and thereby be able to integrate their requirements and considerations into military smokes, obscurants, and riot-control agent studies, risk assessments, and natural resources and mission related training and operations.

This approach was used with the intent of providing and promoting maximum clarity and understanding and minimizing subjective interpretation. Hopefully, this approach will assist the reader and user of this report in gaining a better 
understanding of the background and basic authorities and their interrelationships.

\section{Mode of Technology Transfer}

This report will be made accessible through the World Wide Web (WWW) at URL:

http://www.cecer.army.mil 


\section{Regulation and Policy Overview}

Numerous Federal and State laws deal with, address, and affect fish, wildlife, and other natural resources, as well as threatened and endangered species. The following listed laws and regulations can be considered the primary ones likely to be of interest and importance to the military services. However, many others have elements that may impact directly and indirectly on military smokes, obscurants, and riot-control agent testing and use. Military personnel should consult with appropriate natural resources, fish and wildlife, and environmental personnel with regard to the applicability of other laws and authorities.

\section{Federal Statutes}

\section{Endangered Species Act}

Natural resources management has become increasingly influenced by societal concerns for conserving all species of plants and animals. The Endangered Species Act (ESA) is the primary authority and requirement relative to threatened and endangered species. Enacted by Congress in 1973 and amended at different times since then, the ESA grants substantive protection to all plants and animals determined by the Secretary of the Interior or the Secretary of Commerce to be threatened or endangered. The term "threatened species" is defined as "any species which is likely to become an endangered species within the foreseeable future throughout all or a significant portion of its range" [16 USC 1532(20)]. The term "endangered species" is defined as "any species which is in danger of extinction throughout all or a significant portion of its range" [16 USC 1532(6)]. "Candidate species" are any species being considered by the Secretary of the Interior or of Commerce for listing, under the ESA, as threatened or endangered [50 CFR 424.02(b)]. "Proposed species" are any species that is proposed in the Federal Register to be listed in accordance with the ESA [50 CFR 402.02]. "Critical habitat" means an area which is essential to the conservation of the species, or that that may require special management or protection [16 USC $1532(5)(\mathrm{A})]$.

In addition to providing for protection and conservation, the ESA also addresses (i.e., regulates) the "taking" of listed species. The term "take" is defined to mean to "harass, harm, pursue, hunt, shoot, wound, kill, trap, capture, or collect, or 
attempt to engage in any such conduct" [16 USC 1532(19)]. "Incidental take" is further defined as "taking that results from, but is not the purpose of, carrying out an otherwise lawful activity conducted by a federal agency" [50 CFR 402.02]. Case law and regulatory practice define "take" very broadly, even more broadly than the above wording suggests. For example, activities resulting in the destruction of required habitat may be considered as a "taking" and a violation of the law. It is emphasized that "take" need not be intentional to be considered unlawful.

Five factors are used in evaluating species for listing or conversely delisting under the ESA: (1) the present or threatened destruction, modification, or curtailment of species habitat or range; (2) degree of utilization for commercial, recreational, scientific, or educational purposes; (3) disease or predation; (4) the adequacy of existing regulatory mechanisms; and (5) other natural or manmade factors affecting the species continued existence [16 USC 1533(a)(1)]. Broadly speaking, the military services affect listed species through their active or inactive land management and land use activities.

The requirement for protection and conservation of threatened and endangered species by Federal agencies is not discretionary. In enacting the ESA, Congress set forth specific policy on how all Federal agencies are to address those species. Specifically the ESA states: [Sec. 2 (c)(1), (16 USC 1531(c)(1))] "It is further declared to be the policy of Congress that all Federal departments and agencies shall seek to conserve endangered species and threatened species and shall utilize their authorities in furtherance of the purposes of this Act." In addition, while the ESA applies broadly to all of the country, there are specific directives for Federal agencies.

Section 7(a)(1) of the ESA [16 USC 1536(a)(1)] states that: “... All other Federal agencies shall, in consultation with and with the assistance of the Secretary, utilize their authorities in furtherance of the purposes of this Act by carrying out programs for the conservation of endangered species and threatened species listed pursuant to ... this Act." The ESA also states [Section 7(a)(2), (16 USC 1536(a)(2))]: "Each Federal agency shall, in consultation with and with the assistance of the Secretary, insure that any action authorized, funded, or carried out by such agency ... is not likely to jeopardize the continued existence of any endangered species or threatened species or result in the destruction or adverse modification of habitat of such species which is determined by the Secretary, ... to be critical .... In fulfilling the requirements of this paragraph each agency shall use the best scientific and commercial data available." 
Federal departments and agencies ensure compliance with the ESA in part through consultation with the U.S. Fish and Wildlife Service (FWS), or in the case of marine animals with the National Marine Fisheries Service (NMFS). The consultation component of threatened and endangered species conservation, management, and recovery is required by the ESA. If the FWS or the NMFS advises a Federal agency that a listed species may be present in the area of the agency's proposed action, or if the agency is aware that a listed species may be present, the agency must conduct a biological assessment to determine whether its proposed action is likely to affect any listed species. A biological assessment is prepared by a Federal agency and contains information to determine whether a proposed action is likely to affect proposed or listed species or critical habitat. Such a biological assessment must be completed within 180 days after the date on which it was initiated and before the proposed action commences. If the biological assessment establishes that the proposed action is not likely to adversely affect proposed or listed species or critical habitat, and the FWS or NMFS provides written concurrence, the Federal agency may proceed with the proposed action. If the biological assessment establishes that the proposed action is likely to affect listed species or critical habitat, or likely to jeopardize proposed species, formal consultation with the FWS or NMFS is necessary.

In the formal consultation process, the Federal agency requests initiation of formal consultation. Upon receipt of complete and adequate information on the proposed action and its anticipated effects and impacts, the FWS or NMFS has 135 days to initiate, provide for review by the Federal agency, and to prepare and deliver a biological opinion on the proposed action. In essence, a biological opinion is a document that includes: (1) the opinion of the FWS or NMFS as to whether or not a Federal action is likely to jeopardize the continued existence of proposed or listed species or result in the destruction or adverse modification of critical habitat; (2) a summary of the information on which the opinion is based; and (3) a detailed discussion of the effects of the action on proposed or listed species or critical habitat. If the biological opinion finds that the proposed action would likely jeopardize the continued existence of the species or result in destruction or adverse modification of critical habitat, reasonable and prudent alternatives, if existent, must be proposed to avoid those effects. Additionally, a biological opinion will typically contain a statement or authorization of incidental take. To allow for incidental take, the FWS or NMFS provides a statement of the anticipated incidental take with reasonable and prudent measures to minimize such take.

Terms and conditions to implement the specific reasonable and prudent measures are typically identified and are nondiscretionary and are binding on the agency. The FWS or NMFS may also provide, with the biological opinion, a 
statement containing discretionary conservation recommendations. While these recommendations are advisory, they do reflect the opinion or position of the FWS or NMFS (the lead and primary Federal agencies in fish and wildlife and threatened and endangered species matters) and should be given appropriate and due implementation consideration.

Given the number of species, their wide range of habitats, and a wide range of military smoke, obscurant, and riot-control agent training and testing situations, it has been postulated that exposure to military smokes, obscurants, and riotcontrol agents may affect listed and other species (see Getz et al. 1996; Sample et al. 1997). It is important to consider any effects that may exist and to coordinate with the FWS or NMFS prior to any smoke, obscurant, or riot-control agent action.

\section{Sikes Act}

The Sikes Act (Conservation Programs on Military Installations, PL 105-85, Sec. 101 ) is a basic authority for the management of wildlife and other natural resources on military lands. The Sikes Act specifically provides [16 USC $670 \mathrm{a}(\mathrm{a})(1)(\mathrm{A})]$ that the military services "... shall carry out a program to provide for the conservation and rehabilitation of natural resources on military installations." The Sikes Act specifically requires military installations to carry out a program to provide for (among other things) “... the conservation and rehabilitation of natural resources ...", and "... the sustainable multipurpose use of the resources, which shall include hunting, fishing, trapping, and nonconsumptive uses ..."[16 USC 670a(a)(3)]. The Sikes Act also provides that the military services “... shall prepare and implement an integrated natural resources management plan for each military installation in the United States ..." [16 USC $670 \mathrm{a}(\mathrm{a})(1)]$, and that each integrated natural resources management plan is to be prepared "... in cooperation with ..." the FWS and the State fish and wildlife agency [16 USC 670a(a)(2)]. The integrated natural resources management plan is required to "... reflect the mutual agreement of the parties concerning conservation, protection, and management of fish and wildlife resources." Furthermore, integrated natural resources management plans are required to provide for "... fish and wildlife management, land management, forest management, and wildlife oriented recreation ...", and "... fish and wildlife habitat enhancement or modification" [16 USC 670a(b)]. Significantly, the Sikes Act provides that "[w]ith regard to the implementation and enforcement of integrated natural resources management plans ... priority shall be given to entering into of contracts for the procurement of such implementation and enforcement services with Federal and State agencies having responsibility for the conservation or management of fish or wildlife" [16 USC 670a(d)]. 
As referenced above, Integrated Natural Resources Management Plans (INRMPs), prepared in cooperation with the FWS and the State fish and wildlife agency are mandated by the Congress. The INRMPs must address fish and wildlife (to include threatened and endangered) resources. Depending on the military service and local convention (of the FWS and State fish and wildlife agency) and agreement, component Fish and Wildlife Management (FWMP) and Endangered Species Management Plans (ESMP) may be prepared (see Army Regulation [AR] 200-3 Chapters 6 and 9; Air Force Instruction [AFI] 32-7064 Chapters 6 and 7; Office of the Chief of Naval Operations Instruction [OPNAVINST] 5090.1B Chapter 22; Marine Corps Order [MCO] P5090.2A Chapter 11). To optimize program integration and allow for the conservation and wise use of threatened and endangered and other biological resources, military training and testing requirements should be considered in INRMPs, FWMPs, and/or ESMPs. This is not a one-way street however. As previously discussed, specifically with regard to threatened and endangered species at least, the military services have an obligation to consider species needs, training and testing impacts, and other Federal and State agencies authorities and concerns in their training and testing plans and operations (see 16 USC 1536(a)(2); DoD Instruction [DoDI] 4715.3(F)(b); AR 200-3(3)(34)(a)).

It follows therefore, that the use of smokes, obscurants, and riot-control agents on military installations should be addressed in the installation's INRMP and/or FWMP. To the extent that threatened, endangered, or other species of concern are found on the installation, the use of smokes, obscurants, and riot-control agents should also be addressed in any installation ESMP that is prepared.

\section{Migratory Bird Treaty Act}

The Migratory Bird Treaty Act (MBTA) prohibits, among other things, the taking, pursuing, killing, capturing, or nesting disturbance of migratory birds. "Taking" is defined in 50 CFR 10.12 and includes both "intentional" and "unintentional" take. Almost all birds are considered migratory in the context of the MBTA (see 50 CFR 10.13). The use of military smokes, obscurants, or riotcontrol agents that may result in the disturbance, harm, or killing of migratory birds may present a conflict with MBTA provisions. For example, even if no endangered or threatened birds or other species are present, the release of military smokes, obscurants, or riot-control agents may expose birds, their habitat, and food sources to those agents or otherwise cause a disturbance or disruption to reproductive or other behavior and life history patterns. In the context of using smokes, obscurants, and riot-control agents for training purposes on military lands, any taking of migratory birds that might result would be considered unin- 
tentional since although it may result from, it would not be the purpose of the training or testing activity.

Recently, as part of the National Defense Authorization Act for Fiscal Year 2003 (Public Law [PL] 107-314; enacted 12 December 2002), Congress exempted, for a period of 1 year from the date of enactment, the military services from the incidental take provisions of the MBTA. This exemption is limited to military readiness activities as authorized by the Secretary of Defense or the Secretaries of the respective military services. Military readiness activities are defined as " ... all training and operations of the Armed Forces that relate to combat; ... and the adequate and realistic training of military equipment, vehicles, weapons, and sensors for proper operation and suitability for combat use." [Sec. 315(f)(1)]. Military readiness activities do not include routine military installation operating and support functions, the operation of industrial activities, or the construction or demolition of facilities use for operating and support functions [Sec. 315(f)(2)]. As part of the law, the Secretary of the Interior, with the concurrence of the Secretary of Defense, is required to develop and prescribe regulations to authorize the incidental taking of migratory birds during military readiness activities of the military services. Concurrently, the Secretary of Defense is required to monitor the impacts of military readiness activities on migratory birds, and to minimize and mitigate any adverse impact on affected migratory birds resulting from military readiness activities.

If migratory birds or their habitats are present at the release site or in areas where smokes, obscurants, or riot-control agents may disperse or occur, coordination with the FWS on migratory bird issues, impacts, and effects is advised prior to the release of military smokes, obscurants, or riot-control agents. With the MBTA, as with other Federal laws dealing with wildlife, the effects of normal military mission activities should be considered in the installation INRMP, ESMP, and/or FWMP.

\section{Fish and Wildlife Coordination Act}

The Fish and Wildlife Coordination Act (FWCA) requires that Federal agencies consult with the FWS or NMFS and State wildlife agencies regarding fish and wildlife (including threatened and endangered species) and impacts of projects that affect water resources. Generally speaking, the FWCA applies primarily to activities that affect, control, or modify streams or other bodies of water (e.g., water resource development projects; dams, diversions, channelization, etc.). These types of actions are not normally associated with military training exercises that involve military smokes, obscurants, or riot-control agents. However, a total military training exercise that includes use of military smokes, obscur- 
ants, or riot-control agents may involve temporary or other stream crossings or other water body affects, or the disbursement of smokes, obscurants, or riotcontrol agents at such sites. Under the FWCA, the FWS and NMFS have responsibility for general review of plant and wildlife species issues that may not be considered under other authorities (e.g., ESA or National Environmental Policy Act); for example, the consideration of an action's secondary effects on a wetland. The FWCA requires that Federal agencies must give full consideration to FWS, NMFS, and State wildlife agency recommendations regarding wildlife species.

Most matters related to modification of or effects on water bodies are administered by the U.S. Army Corps of Engineers regulatory offices under authority of the Federal Water Pollution Control Act and amendments. If there is a question about the applicability of the FWCA to military training exercises involving smokes, obscurants, or riot-control agents, the appropriate Corps regulatory or FWS or NMFS office should be contacted.

\section{Federal Water Pollution Control Act}

The Federal Water Pollution Control Act with its many amendments, commonly referred to as the Clean Water Act (CWA) is the main authority addressing matters of surface water resources in the nation. Overall, the law stipulates broad national objectives to "restore and maintain the chemical, physical, and biological integrity of the Nation's waters" [33 USC 1251(a)]. An important focus of these objectives is to restore and maintain surface water suitable for fish, aquatic life, and human health. Important provisions of the CWA include those involving discharges to navigable waters, limitations on point sources, procedures for state water quality standards, nonpoint source pollution, and water quality inventory requirements. Some provision of the CWA are administered and regulated by the U.S. Army with overview by the U.S. Environmental Protection Agency (EPA). Specifically, Section 404 of the act authorizes the Corps of Engineers to issue permits for alterations to wetland and navigable waters [33 USC 1344]. Other provisions of the CWA are typically administered and enforced by the various states with EPA oversight.

Specific water quality and water pollution control criteria, restrictions, and requirements vary to some degree with the state. In addition, each state typically has its own water quality and water pollution control programs and procedures. To complicate matters, within each state, different surface waters may have different water quality and other criteria. During training or testing exercises, military smokes, obscurants, or riot-control agents or their constituent components that are released may come in contact with surface waters and associated 
aquatic life. The degree to which this contact is addressed or can be accommodated in accordance with the CWA, or under State and other regulations promulgated under the CWA, should be determined.

The use of military smokes, obscurants, and riot-control agents and effects and impacts on surface waters and associated aquatic life, as related to the CWA, should be addressed with the appropriate State environmental agency.

\section{Clean Air Act}

The Clean Air Act (CAA) is the comprehensive Federal law that regulates air emissions from area, stationary, and mobile sources. This law authorizes the EPA to establish National Ambient Air Quality Standards to protect human health and the environment. States generally implement and carry out the CAA through State Implementation Plans and the issuance of permits for the release of pollutants. Military smokes, obscurants, and riot-control agents are composed of a number of chemical compounds, gasses, and particulate matter. Some of these constituents, for example particulates and volatile organic compounds, in addition to individually or collectively having established specific emission criteria, may affect life forms. In addition, the release of military smokes, obscurants, and riot-control agents may relate to established local, regional, and State ambient air quality standards, and permit authorization.

Training and natural resources managers need to inquire about the effects of smokes, obscurants, and riot-control agents on State or other air quality and other standards before using the materials. Similarly, they should coordinate with the appropriate State environmental agency on the relationship of the potential effects of smokes, obscurants, and riot-control agents on the environment. This should be a part of the installation air quality management plans and, as with other laws, part of an installation INRMP.

\section{National Environmental Policy Act}

The National Environmental Policy Act (NEPA) establishes a national environmental policy with goals for the protection, maintenance, and enhancement of the environment, and provides a process for implementing these goals within Federal agencies. A main objective of NEPA is to create a better decisionmaking processes and foster better decisions for implementing projects and programs that could adversely impact the environment [40 CFR 1501(c)]. NEPA requires Federal agencies to incorporate environmental considerations in their planning and decisionmaking process, and requires the use of a systematic and interdisciplinary approach to doing so. Specifically, Federal agencies must formally 
evaluate the environmental impacts of any major actions that could significantly affecting the quality of the human environment and consider all reasonable alternatives. Importantly, NEPA requires that environmental information be available not only to public officials but also to the public citizenry before decisions are made and actions are taken [40 CFR 1501(b)].

Major actions include any new or continuing Federal activity including projects and programs financed, assisted, conducted, regulated, or approved by Federal agencies and are subject to NEPA [40 CFR 1508.18]. In addition to the National Council on Environmental Quality Regulations [40 CFR 1500-1508], some military services (i.e., Army and Air Force) have promulgated additional and similar rules for the implementation of NEPA (U.S. Army 1988; U.S. Air Force 1999). These rules and regulations specify processes and procedures to be followed to comply with NEPA.

Compliance with NEPA is independent of compliance with the ESA. However, the procedures, documentation, analysis, and decisionmaking processes followed are not intended to be duplicative but rather provide for joint preparation with other local, State, and Federal agencies and, with other Federal procedures, provide for adoption of appropriate environmental documentation prepared by other agencies and in conformance with other statute [40 CFR 1500.5; 50 CFR 402.12(g); 40 CFR 1506.2].

The release and use of military smokes, obscurants, and riot-control agents for training and testing purposes, particularly if threatened or endangered species are involved (see 40 CFR 1508.27(b)(9)), is subject to the requirements of NEPA. An identification, analysis, and evaluation of the possible impacts and effects on threatened and endangered species resulting from the use of military smokes, obscurants, and riot-control agents would be information (but not the only information) included in the NEPA process and documentation. For example, a biological assessment addressing the use or release of military smokes, obscurants, or riot-control agents, prepared in accordance with the ESA and accepted by the FWS or NMFS, should satisfy that portion of NEPA analysis requirements relative to the species and/or ecological systems addressed in the biological assessment. Similarly, a biological opinion issued by the FWS or NMFS should carry considerable weight in determining not only potential reasonable and prudent alternatives but also potential mitigation for any affected threatened or endangered species [50 CFR 402.02; 40 CFR 1502.14; 40 CFR 1508.2].

However, solely implementing a NEPA process does not ensure compliance with the ESA. NEPA is intended to help and support informed environmental deci- 
sionmaking on the part of Federal agencies. It does not negate requirements, actions, or decisionmaking mandated by other authorities such as the ESA.

\section{Marine Mammal Protection Act}

The Marine Mammal Protection Act (MMPA, PL 92-552) establishes a Federal responsibility to conserve marine mammals with the taking (including harassing and annoyance) of such mammals being regulated. In addition to protection under the MMPA, many marine mammals are also protected under the ESA. Both the FWS and the NMFS have regulatory authority over marine mammals (16 USC 1361-1407). The FWS has authority for walruses (Odobenus sp.), polar bears (Ursus maritimus), and manatees (Trichechus sp.), while the NMFS manages whales and porpoises (Cetacea), seals, and sea lions (Pinnipedia). The two agencies may issue permits (16 USC 1374) that authorize the taking of marine mammals.

\section{Magnusen-Stevens Fishery Conservation and Management Act}

The Magnusen-Stevens Fishery Conservation and Management Act (MSFCMA) (including provisions as reauthorized by Sustainable Fisheries Act Amendments) recognizes that certain marine fishes have been drastically reduced or have declined to a point where their survival is threatened. Under the law, essential fish habitat is defined as "... those waters and substrate necessary to fish spawning, breeding, feeding, or growth to maturity" [PL 104-297, Sec. 102(10)]. In accordance with MSFCMA provisions, Federal agencies must consult with the NMFS prior to undertaking any actions that may affect essential marine fish habitat.

\section{Coastal Zone Management Act}

The Coastal Zone Management Act (CZMA) establishes a national policy that includes the preservation, protection, restoration, and enhancement "of natural resources, including wetlands, floodplains, estuaries, beaches, dunes, barrier islands, coral reefs, and fish and wildlife and their habitat, within the coastal zone" [16 USC 1452(2)(A)].

Coastal zones are defined as coastal waters and adjacent shorelands (including islands, transitional and intertidal areas, salt marshes, wetlands, and beaches). Coastal zones include areas in states bordering on the Atlantic, Pacific, or Arctic Oceans, the Gulf of Mexico, and the Great Lakes. Federal agencies must carry out any activities consistent with those of other Federal agencies and State coastal zone management programs [16 USC 1456(a); 16 USC 1456(c)(1)(A)]. 
Military installations within identified coastal zones are subject to provisions of the CZMA.

\section{State Laws}

It is commonly and legally established, under the public trust doctrine, that wildlife and other natural resources are "held in trust" for the people by the States and the Federal government (see for example the Comprehensive Environmental Response, Compensation, and Liability Act, 42 CFR 9607(f)(1)). In some instances, Federal and State (or other, e.g., Tribal) governments may assert trusteeship over the same natural resource. Wildlife may for example, migrate or move back and forth between Federal and State lands and Federal and State agencies may have overlapping areas of management authority. As a general rule, in the exercise of their broad general governmental powers, States possess broad trustee and police powers over fish, wildlife, plants, and their habitats within their borders. Unless preempted by Federal authority, States possess primary authority and responsibility for protection and management of fish, wildlife, and plants and their habitats (see Federal Register 59-34275, July 1, 1994).

States generally hold and retain jurisdiction over Federal lands within their boundaries. That jurisdiction is typically proprietary (i.e., State laws generally apply) or concurrent with Federal law (i.e., a combination of State and Federal laws apply). However, under the Property Clause of the Constitution (Article IV), Congress has the power to enact legislation respecting Federal lands and when Congress so acts, under the Supremacy Clause (Article VI), the Federal legislation overrides conflicting State laws (Coggins et al. 1993; Bean and Rowland 1997; U.S. Supreme Court 1976). So long as State law is not in conflict with Federal law, at the very least Federal agencies are obliged to consider State laws and requirements with regard to wildlife and related natural resources. In fact, in some instances (e.g., ESA, 16 USC 1535; Sikes Act, 16 USC 670a(2); FWCA, 16 USC 661-667) the Federal government is specifically required to cooperate and/or mutually agree on the conservation, protection, and management of threatened, endangered, fish, and wildlife resources, and their habitats, with the States. This would include wildlife and other biological resources identified as threatened or endangered by the respective States.

Consequently, to the extent that military smokes, obscurants, and riot-control agents may affect fish and wildlife resources, the use of these materials should be addressed with the appropriate State fish and wildlife agency. 


\section{Department of Defense and Other Regulations}

\section{Department of Defense Directive}

Department of Defense Directive 4700.4 - Natural Resources Management Program, prescribes policies and procedures for management of natural resources on property under DoD control. DoDD 4700.4 (4)(4.3) states: "Watersheds and natural landscapes, soils, forests, fish and wildlife, and protected species shall be conserved and managed as vital elements of DoD's natural resources program."

\section{Department of Defense Instruction}

Department of Defense Instruction (DoDI) 4715.3 - Environmental Conservation Program, implements policy, assigns responsibilities, and prescribes procedures for the integrated management of natural resources under DoD control. With regard to threatened and endangered species, DoDI 4715.3(D)(2)(c) states: "Biologically or geographically significant or sensitive resources (e.g., wetlands, forests, floodplains, watersheds, estuaries, riparian areas, costal barrier islands, marine sanctuaries, critical habitats, animal migration corridors) or species (e.g., threatened or endangered species, certain marine mammals, and migratory birds) shall be inventoried and managed to protect those resources and to promote biodiversity ..." Also, the instruction further states [DoDI 4715.3(F)(b)]: "Each DoD component shall ensure that current and planned installation programs, plans, and projects (e.g., training and test range management plans, master plans, integrated pest management plans, endangered species recovery plans, golf course management plans, grounds maintenance plans, facilities construction site approvals, and other land use activities) are integrated and compatible with natural and cultural resources programs, plans, and projects."

The importance of DoDD 4700.4 and DoDI 4715.3 is that they both:

- recognize the importance of threatened and endangered and other wildlife to the national well-being;

- recognize and acknowledge the role of the military services in protecting those national resources; and,

- direct the military services to specific actions and considerations with respect to those resources.

\section{Army Regulations}

Army Regulation (AR) 200-3, Natural Resources - Land, Forest and Wildlife, sets forth policy, procedures, and responsibilities for the conservation, management, and restoration of land, natural resources, and fish and wildlife for the 
Army. The regulation is comprehensive and visionary in scope. The Army is committed to being a national leader in conserving listed species [AR 2003(11)(111)(a)] and maintaining biological diversity [AR 200-3(11)(111)(c)]. On installations with listed species, critical habitat, or other environmentally sensitive natural resources, training and testing directorates are required to establish a mandatory, ongoing awareness program for all personnel who may have contact with listed species or their habitat [AR 200-3 (2)(26)(b)]. The Army Integrated Training Area Management Program is required to comply with Federal, State, and local standards, including ESA, NEPA, and State wildlife laws [AR 200-3(3)(34)(a)]. If federally proposed or listed species, or State listed species are found on an Army installation, an ESMP [AR 200-3(11)(115)(a)] must be prepared, either by itself, or as part of the required INRMP [AR 200-3(9)(91)(a)] (or Fish and Wildlife Cooperative Plan [AR 200-3(6)(64)] as outlined in the Sikes Act). The Army specifically requires that management emphasis be placed on the maintenance and restoration of habitat favorable to threatened and endangered species as well as fish and wildlife [AR 200-3(6)(61)(a)].

In all instances involving Federal or State proposed or listed species, NEPA considerations must be addressed and met [AR 200-3(2)(22)(a); AR 200$3(11)(114)(b)]$.

\section{Navy Regulations}

The Office of the Chief of Naval Operations Instruction (OPNAVINST) 5090.1B, Navy Environmental and Natural Resources Program Manual, establishes and summarizes program requirements, guidelines, and standards for complying with natural resources protection laws, and conserving and managing Navy lands, waters, fish and wildlife, threatened and endangered species, and other natural resources. The Navy has specifically indicated that its policy is to use its authority to further programs for the conservation of endangered and threatened species [OPNAVINST 5090.1B (22)(4.2)(a)].

When the Navy proposes, and before it takes any action that modifies any stream or body of water, Navy regulation requires consultation with the FWS or NMFS and the appropriate State agency and must fully consider the fish and wildlife aspects of the proposed action [OPNAVINST 5090.1B(22)(4.2)(f)].

The Navy is quite possibly unique among the military services in that obligations under the MMPA must be addressed on a regular basis. Also, because of its role in national defense, the Navy also is more likely to be involved with the implementation of provisions of the MSFCMA than are the other military ser- 
vices. Similarly, as a generalization, CZMA provisions are more likely to apply to Navy installations as a whole than those of the other military services.

\section{Air Force Regulations}

Air Force Instruction 32-7064, Integrated Natural Resources Management, implements DoDI 4715.3, Environmental Conservation Program, and provides guidance, in conjunction with other Federal, State, and local laws and standards for natural resources management. The Air Force has established that the chief tool for managing Air Force installation ecosystems is the INRMP [AFI 327064(2)(2.1)]. The Air Force requires that biodiversity conservation be promoted [AFI 32-7064(2)(2.2)] and establishes a goal of no net loss of wetlands [AFI 32 7064(3)(3.1)].

The Air Force also requires that installations specifically address fish and wildlife management [AFI 32-7064(6)(6.1)(6.1.2)] and that cooperative agreements with the FWS and State wildlife agency for "... protecting, conserving, and managing fish and wildlife resources ..." be developed and implemented [AFI 327064(6)(6.1)(6.1.3)]. Additionally, Air Force installations with listed species must develop and implement a threatened and endangered species management plan that includes candidate species as well as State listed species [AFI 327064(7)(7.1), AFI 32-7064(7)(7.1)(7.1.1), AFI 32-7064 (7)(7.3)(7.3.2)]. The Air Force also recognizes the potential need for research on natural resources, including threatened and endangered species [AFI 32-7064(14)(14.5)].

\section{Marine Corps Regulations}

Marine Corps Order P5090.A, Environmental Compliance and Protection Manual, implements the requirements of DoD environmental policy. The Marine Corps recognizes that in order to provide for sustained military use of its lands, natural resources must be conserved and managed [MCO P5090.A (11)(1)(11104)(1)(a)]. As policy, natural resources under the stewardship and control of the Marine Corps will be managed to preserve, protect, and enhance those resources $[\mathrm{MCO}$ P5090.A (11)(2)(11200(1); $\mathrm{MCO}$ P5090.A (11)(2)(11200(1)(b)] to include ecosystem integrity and biological diversity [MCO P5090.A(11)(2)(11200)(2)].

The Marine Corps has clearly articulated its position on threatened and endangered species by stating it "... will use its authority to further programs for the conservation of endangered and threatened species ..."; “... will assist the USFWS and NMFS in their efforts to prepare recovery plans for endangered species" [MCO 5090.A(11)(1)(11104)(3)(a), MCO 5090.A(11)(2)(11202)(1)]; and 
"will...conserve and promote conservation of nongame fish and wildlife and their habitats" [MCO 5090.A(11)(1)(11104)(3)(d)]. Cooperative management and cooperative agreements with Federal and State fish and wildlife agencies are also required [MCO 5090.A(11)(1)(11104(3)(e), MCO 5090.A(11)(2)(11202)(3)(a) and (b)]. The Marine Corps specifically prohibits the introduction of exotic species [MCO P5090.A (11)(1)(11104)(1)(h), MCO P5090.A(11)(2)(11200)(7)]. 


\section{Related Reports}

\section{This Series}

Volume 2: Methods for Assessing Ecological Risks (Sample et al. 1997) presents an approach for selecting suitable methods to evaluate ecological risks that smokes, obscurants, and riot-control agents present to threatened and endangered species; summarizes available sampling, survey, and toxicity testing methods; and outlines an approach for estimating risks using multiple lines of evidence.

Ecological risk assessment is a process for collecting, organizing, and analyzing information to help provide an estimate of the likelihood of typically undesired effects on ecosystems or nonhuman organisms (Suter et al. 2000). Although typically applied at previously existing and suspected contamination sites (USEPA 1989b), the process can also be used to estimate the risk of the application of stressors (e.g., military smokes, obscurants, and riot-control agents) to individual or collective elements of the ecosystem (e.g., threatened or endangered species). Some efforts at biological and/or risk assessment relative to military smokes, obscurants, and similar agents have been made (see U.S. Army 1996). Unfortunately, the bulk of these efforts have not been widely reported or disseminated. In a broader context, risk assessment approaches are also being applied to larger ecologically related issues including encroachment and limitations on military use of military and other lands as well as the fragmentation of wildlife habitats (Deal et al. 2002).

Ecological risk assessment consists of four interrelated elements: problem formulation, exposure assessment, effects assessment, and risk characterization. In a sense, risk characterization is the end point in that it integrates information and data on exposure and response to evaluate the likelihood of adverse effects attributable to the exposure to chemical or other contaminant stressors. A distinction must be made between risk assessment and risk management. Risk management can be described as the process of deciding what remedial, restoration, or mitigation actions to take, justifying the decision, and implementing that decision. Although risk management can be a part of risk assessment, it should generally follow risk assessment. 
Ecological risk assessment is consistent with the NEPA process and can provide a consistent and supportable way of organizing and conducting technical analyses that contribute to Environmental Impact Statements and related environmental assessments. It does not conflict with nor does it replace the procedural requirements of NEPA. For a specific discussion of environmental assessment in the context of smokes and obscurants, see documents by Shinn et al. (1987a, 1987b).

In a broad context, ecosystem management requires assessment of the risks to ecosystems from all, not just individual actions that may potentially affect them. The ecological risk assessment process as used by the military allows risks from multiple and diverse stressors to be addressed. However, it is important to recognize that the general approach to ecological risk assessment is one of focusing primarily on populations and communities of organisms and not on the effects to individual organisms. The ESA, somewhat in contrast, requires evaluation and consideration of protection for individuals of a species. It is extremely important to recognize that strictly speaking, ecological risk assessment per se is not designed to directly support management or other actions regarding threatened or endangered species (Whitworth 1994).

In dealing with threatened or endangered species, or for that matter other fish, wildlife, and related biologic resources, it is important to recognize that ecologic risks may result not only from the direct action of a stressor on an endpoint receptor, but also from indirect effects influenced by trophic level, life stage, habitat, and a multitude of other variables. Also, remember that military training and testing programs frequently involve multiple activities with multiple stressors and occurrences. These combined exposures, effects, and potentially resulting risks associated with multiple stressors and stress events can result in cumulative effects or risks, and obviously complicate evaluation.

Volume 3: Statistical Methods (Cassels et al. 2001) identifies and recommends strategies for developing statistically sound approaches to assessing the effects of military smokes, obscurants, and riot-control agents on threatened and endangered species, and considers strategies and statistical analysis procedures to evaluate environmental effects of those agents.

The report provides an overview of sampling designs and statistical procedures for evaluating the effects of smokes, obscurants, and riot-control agents in terrestrial and aquatic ecosystems. The report lays a basic foundation for understanding the principles of experimental design and statistical analysis procedures in an ecological context. In addition, the report identifies strengths and weaknesses of pertinent experimental design and applied statistical analysis. In 
considering biological systems, the evaluator must interpret the results of the study in the context of the nature and magnitude of effects, the space and time patterns of effects, the likelihood that effects will occur in a natural context, and the recovery potential of the biological system in which the effects are observed. This report discusses statistical significance and ecological significance and relates the use of statistics in modeling for effects assessment and to help quantify uncertainty (Sample et al. 1997).

The report also discusses special considerations necessary for sampling air, soil, water, and biota. Because military smokes and obscurants can consist of exotic materials not found in more common industrial and agricultural air and other pollutants, conventional pollution dispersion models, sampling and statistical methods, and field research techniques may not be applicable and should be approached cautiously. Air models specific for military smokes have been researched and developed (Bowers and White 1992) and should be used whenever possible. Soil sample collection is fairly straightforward (Sandusky 1992). There are however, considerations of loss of volatile compounds, transformations through biological activity, photolysis, and chemical movement attributable to leaching or animal activity that should be taken into account. Sampling for military smoke and obscurant compounds in water presents other problems (Rand 1995). Water movement and temperature, and compound solubility and specific gravity can be important considerations. Keith (1991) addresses many soil and water sampling approaches and protocols. For biotic sampling, body size, trophic level, developmental or life cycle stage, and life form itself are also important considerations (see Shore and Rattner 2001).

For collecting and sampling various biota, including vegetation (Simini 1992) and particularly higher vertebrate forms, field and research personnel need to be aware of and comply with the various State and Federal jurisdictional requirements that may exist. Most, if not all, states for example have collection application and/or permitting requirements for the taking (collecting) of fish and wildlife. In some cases, even the collection of common species, migratory birds for instance, may require Federal and State authorization. Investigative personnel should consult with the State fish and wildlife agency before initiating any biotic collection or analysis investigation. For higher life form collection and sampling, Bookhaut (1996) and Backiel and Welcomme (1980) provide valuable information and references.

Volume 4: Chemical Analytical Methods and unattached Appendices (Nam et al. 1999) examines methods for isolating and detecting compounds in smokes, obscurants, and riot-control agents for biological as well as abiotic media. Generally, there are three basic types of smokes used for military obscurant purposes: 
fog oil smoke, hexachloroethane (HC) smoke, and white phosphorous (WP) smoke. In addition, other smokes agents are used for more specific purposes such as colored smokes for signaling, o-chlorobenzalmalononitrile (CS) and others as an eye, nose, mouth, and respiratory tract irritant used in riot and crowd control, and smoke with brass or graphite powder or flakes used to screen infrared/electromagnetic signals. Because of the widely varying chemical characteristics of the various smokes compounds, many different analytical tests and testing protocols are available and may be appropriate.

The report provides a starting point for performing analysis for the detection, identification, and quantification of obscurant smoke residues in field soil, water, and air samples. Both standard and nonstandard methods are identified. For the most part, standard analysis methods for the various smokes, obscurants, and riot-control agents have been identified (see USEPA 1983, 1988, 1991a, 1991b, 1993a, 1995; see also ASTM 1994). However, as is pointed out, other analytical methods exist and it would be valuable for additional or developing methods and techniques to be researched prior to undertaking what can be costly and time-consuming analytical effort.

\section{Other Resources}

The general ecological risk assessment framework has been published and applied by other Federal agencies (USEPA 1992, 1998), and texts on its application have been prepared and should be consulted (Suter 1993; Suter et al. 2000). Although ecological risk assessments are more complex and differ in approach from human health risk assessments, knowledge of human health risk assessment approaches (USEPA 1989a) is useful to wildlife and fisheries biologists and risk assessors. Specific guidance for the military application of ecological risk assessment has been developed (Wentsel et al. 1996; Suter et al. 2001) and should be consulted and applied in smoke and obscurant investigations as appropriate. Other useful information and background on ecological risk assessments is contained publications in by Deliman et al. (2000), and Whelan et al. (1999). Specific suggestions and guidance on ecological risk assessment data collection and the selection assessment and measurement endpoints has been published by the U.S. Army (Walker 2002; Checkai et al. 2002). An important consideration in military smoke, obscurant, and riot-control agent investigations is that effects may be acute or short-term or chronic or long-term or both (Hoffman et al. 1995).

Some coastal and maritime issues and needs as related to threatened and endangered species have been identified by Gehlhausen and Harper (1998). A broader discussion of general ecological study design and analysis has been pre- 
pared by Krzysik (1998). Field and research personnel would do well to consult Bookhout (1996) for advice on many elements of sampling and collection. Statistical and data analysis approaches as may be used by and of interest to natural resources and wildlife and fisheries biologists include those presented by Green (1979), Kachigan (1986), Campbell (1989), Snedecor and Cochran (1989), Sokal and Rohlf (1995) and Zar (1999).

In dealing with complex ecological issues, models as representations or abstractions of systems or processes can be useful. Models may be helpful in assessing exposure and effects of smokes, obscurants, and riot-control agents on threatened and endangered species. Suter (1999) has presented an informative discussion of the applicability of modeling considerations. However, models are just that - models, and their use and interpretation must be qualified. Ideally, models should be inexpensive and should require no more expertise to operate than is already present in the personnel apt to use the model. Some military smoke and obscurant modeling efforts have been put forth and the reader should be aware of them (see Liljegren et al. 1989; Policastro et al. 1989a, 1989b; Bowers and White 1992; Lozar and Hanson 1997). In addition, Lozar (2002) has developed methodologies for linkage of standard air dispersion models and geographic information system techniques to allow for the prediction of potential biological exposure to obscurant smoke application at the military installation level.

For broader and in some instances more comprehensive overviews of issues and concern associated with the use of military smokes, obscurants, and riot-control agents, in ecological and other contexts, the reader is encouraged to review the information presented by Trame and Tazik (1995), Schaeffer et al. (1986, 1987), Getz et al. (1996), and Cataldo et al. (1989). Fog oil exposure standards and elements of inhalation toxicology are discussed by Palmer (1990) and Grose et al. (1986), respectively. Other information of interest, use, and applicability in threatened and endangered species related military smoke, obscurant, and riotcontrol agent investigations is that related to exposure. The single most comprehensive source of exposure related information is that prepared by the U.S. Environmental Protection Agency (USEPA 1993b). The basic text in toxicology has been considered to be that of Klaassen et al. (1986).

Various authors have presented additional and more specific information regarding military obscurants and other agents, including those containing graphite and powdered brass (Guelta and Checkai 1995; Driver et al. 1993a; Wentsel 1986; Wentsel and Guelta 1986; Hancox 1989; Cataldo et al. 1990), anthraquinone (Sendelbach 1989), fog oils (Driver et al. 1993b; Katz et al. 1980), 
HC smoke (Shinn et al. 1987a), CS gas (Keller et al. 1986), and phosphorus (Berkowitz et al. 1981).

Fog oil and other smokes and obscurants and similar agents have been in longterm, wide, and continuing use in military applications (Muhly 1983; Cichowicz 1983). Grose et al. (1986), Cataldo et al. (1989) and Driver et al. (1993a; 1993b) present a review of health, environmental, and other effects some military smokes. Schaeffer et al. $(1986 ; 1987)$ reported some data and information on field and laboratory exposures of vegetation (Tradescantia, Ambrosia) and native rodents (Perognathus, Peromyocus, Neotoma, Dipodomys spp.,) to obscurant smokes. Overall, however, few studies of the effects of smoke releases on biologic entities or systems have been reported. Consequently, existing data is generally lacking or inadequate to provide an accurate assessment of the potential impacts of smokes, obscurants, and riot-control agents, as used by the military, on most threatened and endangered species (Getz et al. 1996). However, the Army is and has undertaken investigations to address these data and information needs.

\section{Relevant Military Smoke, Obscurant, and Riot-Control Agent Studies}

In part because of difficulties inherent with the study of species with low or limited numbers, populations, and/or distribution (i.e., threatened and endangered species) surrogate species are sometimes used. Recently Driver et al. (2002a, $2002 \mathrm{~b}, 2004)$ reported on the exposure effects of fog oil smoke on two common passerines, the house sparrow (Passer domesticus) and red-winged blackbird (Agelaius phoeniceus), used as surrogates for the red-cockaded woodpecker ( $\mathrm{Pi}$ coides borealis). In summary, these studies indicate:

- acute toxicity of inhaled fog oil from obscurant aerosols is low for adult redwinged blackbirds;

- uptake of fog oil is minimal for red-winged blackbirds and birds of similar size-specific inhalation rates, feather mass, and dermal surface area;

- no adverse effects (i.e., mortality, body weight loss, clinical signs of toxicology, behavioral abnormalities, weight loss, or gross or histopathological lesions) were observed in red-winged blackbirds exposed to worst case scenario fog oil concentrations of up to $400 \mathrm{mg} / \mathrm{m}^{3}$;

- no adverse effects (i.e., hatchability, fledgling production, fledgling success) were observed in house sparrows eggs exposed to fog oil concentrations of up to $450 \mathrm{mg} / \mathrm{m}^{3}$;

- high field concentration exposure (up to $450 \mathrm{mg} / \mathrm{m}^{3}$ ) of house sparrows and red-winged blackbirds to fog oil obscurant smoke did not result in mortality, long-term organ dysfunction, sublethal gross lesions, significant histopathol- 
ogy, immunomodulation, nonspecific immune dysfunction, or end point metabolites.

Based on this information, it appears that under normal military training situations and scenarios involving fog oil smoke, impacts and effects on birds, including the red-cockaded woodpecker, are negligible or nonexistent. 


\section{Issues}

The land available for military training and operational readiness is not unlimited. Acquiring additional land for military training purposes is possible to a limited degree. However, fiscal constraints and the level of planning necessary make such actions difficult. NEPA requirements for example, would require an in-depth and comprehensive review of such an undertaking. Public approval of large-scale land acquisition may or may not be forthcoming.

By definition and intuition, military (i.e., Army and Marine Corps) ground training can be intensive and disruptive of natural and ecological sites and systems. Dramatic or acute stresses and disruptions are generally easily recognized. However, ecological and biological organisms and systems that are continually or chronically stressed through intensive or extensive military activities may take many years to exhibit obvious symptoms of that stress. Prudence and good military planning and stewardship dictate that the quality of existing military training lands must be maintained indefinitely.

That, in reality, is the central issue - the maintenance, in perpetuity, of military lands to support military training while at the same time complying with all appropriate Federal and State laws and regulations.

U.S. Army information needs regarding threatened and endangered species are relatively straightforward (Tazik and Pierce 1994):

- what species (including Federal or State listed, species with listing warranted but precluded, proposed, candidate, and general species of concern) exist on Army lands?

- what are the impacts of Army activities on those species?

- what mitigation and management measures are the most efficient and have the least impact on the Army mission?

Information needs for the other military services are no doubt similar.

To a large degree, through the Integrated Natural Resources and Endangered Species Management Plans and processes required by the Sikes Act, the Army (as well as the other military services) has identified and continues to identify those species found on DoD lands (see Bak et al. 2002, Schreiber and Reed 1999, Shaw et al. 1998, Schreiber et al. 1997, Shaw and Hill 1996). The information 
contained in this report and Volumes 2, 3, and 4 of this series, is intended to help address the information needs relative to the impacts, mitigation, and management of military smokes, obscurants, riot-control agents, and similar compounds. 


\section{Recommendations}

The recommendations provided herein are directed toward addressing Army related concerns. For example, the species mentioned are, for the most part, those identified by the Army as ones of primary interest for Army installations and Army training and operations missions and activities (see U.S. Army 2001, 2002). Other species not specifically mentioned may be of greater interest to the other military services. Nonetheless, the information and recommendations provided should be generally applicable to those and other fish and wildlife species as well.

- The best available information on the effects of fog oil smoke on birds is contained in the studies of red-winged blackbirds and house sparrows by Driver et al. (2002a, 2002b, In Review). These studies strongly support the contention that limited exposures to fog oil releases, such as those that might be encountered in military training exercises, have no measurable effects on passerine and similar sized birds. However, it would be desirable to replicate or complement those studies with additional study of fog oil and/or other smokes on representatives of other avian phylogenetic groups. Such studies would address, to an even greater degree of confidence, any effects of fog oil or other smokes or agents on other avian species of potential concern to the Army.

- Little if any information is available on the effects of fog oil and other smokes and obscurants on other vertebrate and invertebrate species. Studies of other taxonomic groups are needed with special attention focused on endangered species that are currently affecting military training activities as well as species whose future listing could impact military training activities.

- The use of biomonitors for short- and longer term monitoring of chemical and other environmental stressors could be implemented at Army installations where smokes, obscurants, and/or riot-control agents are used in training. While such monitoring may be more significant than monitoring of specific exposure events, monitoring of specific exposure events might be relatively easily integrated into monitoring efforts and protocols such as those being developed through the Strategic Environmental Research and Development Program (SERDP) Ecosystem Characterization and Monitoring (SEMP) Initiative (see Balbach et al. 2001, 2002). 


\section{References}

American Society for Testing and Materials (ASTM). 1994. Annual Book of ASTM Standards, "Section 11, Water and Environmental Technology." Vol 11.01 and 11.02. ASTM, Phildelphia, PA.

Bak, J., S. Sekscienski, and B. Woodson. 2002. Installation Summaries from the FY 2000 Survey of Threatened and Endangered Species on Army Lands. SFIM-AEC-EQ-TR-20018. U.S. Army Environmental Center, Aberdeen Proving Ground, MD.

Backiel, T., and R.L. Welcomme, eds. 1980. Guidelines for Sampling Fish in Inland Waters. Food and Agri. Organization of the United Nation, Rome, Italy.

Balbach, H.E., W.D. Goran, T. Aden, D.L. Price, M. R. Kress, W.F. DeBusk, A.J. Krzysik, V.H. Dale, C. Garten, and B. Collins. 2001. Strategic Environmental Research and Development Program (SERDP) Ecosystem Management Report (SEMP) FY 00 Annual Report. ERDC SR-01-3. U.S. Army CERL, Champaign, IL.

Balbach, H.E., W.D. Goran, T. Aden, D.L. Price, M. R. Kress, W.F. DeBusk, A.J. Krzysik, V.H. Dale, C. Garten, and B. Collins. 2002. Strategic Environmental Research and Development Program (SERDP) Ecosystem Management Report (SEMP) FY 01 Annual Report. ERDC SR-02-2. U.S. Army CERL, Champaign, IL.

Bean, M.J., and M.J. Rowland. 1997. The Evolution of National Wildlife Law. Praeger Publishers, Westport, CT.

Berkowitz, J.B., G.S. Young, R.C. Anderson, A.J. Colella, W.J. Lyman, A.L. Preston, W.D. Steber, R.G. Thomas, and R.G. Vranka. 1981. Occupational and Environmental Hazards Associated with Formulation and Use of White Phosphorus-Felt and Red PhosphorusButyl Rubber Screening Smokes. Final Report. DAMD-17-79-C-9139. U.S. Army Medical Research and Development Command, Ft. Detrick, Frederick, MD.

Bookhout, T.A., ed. 1996. Research and Management Techniques for Wildlife and Habitats. The Wildlife Society. Allen Press, Lawrence, KS.

Bowers, J.F. and J.M. White. 1992. "Air Quality Modeling for Smoke/Obscurant Pretest Environmental Assessment.” In Gerard, S. and W. Klimek eds., Proceedings of the Smoke/Obscurants Symposium XVI, Volume II. U.S. Army Technical Report CREDECCR-184. pp 795-810.

Cassels, D.M., A.J. Krzysik, and K.A. Reinbold. 2001. Methods for Field Studies of the Effects of Military Smokes, Obscurants, and Riot-control Agents on Threatened and Endangered Species. Volume 3: Statistical Methods. TR-01-59, ADA395028 U.S. Army ERDC/CERL, Champaign, IL. 
Campbell, R.C. 1989. Statistics for Biologists. Cambridge Univ. Press, New York.

Cataldo, D.A., P. VanVoris, M.W. Ligotke, R.J. Fellows, B.D. McVeety, S.W. Li, H. Bolton, and J.K. Frederickson. 1989. Transport, Transformations, Fate, and Terrestrial Ecological Effects of Fog Oil Obscurant Smokes. Report No. PNL 6799, Project No. 84PP4819, Pacific Northwest Laboratories, Richland, WA.

Cataldo, D.A., M.W. Ligotke, H. Bolton Jr., R.J. Fellows, P. Van Voris, J.P Mckinlely, S.W. Li, and K. McFadden. 1990. Evaluation Characterization of Mechanisms Controlling Fate and Effects of Army Smokes. Transport, Transformations, Fate, and Terrestrial Ecological Effects of Brass Obscurants. Project Order No. 89PP9903. Final Report. U.S. Army Medical Research and Development Command, Ft. Dertick, MD.

Checkai, R.T., M.S. Johnson, and M.S. Hawkins. 2002. Selection of Assessment and Measurement Endpoints for Ecological Risk Assessment. SFIM-AEC-ER-TR-2002018. U.S. Army Environmental Center, Aberdeen Proving Ground, MD.

Cichowicz, J.J. 1983. Programatic Life Cycle Environmental Assessment for Smoke/Obscurants, Vol. 4 of 5, HC Smoke. Report ARCSL-ES-83007, AD-141973. U.S. Army Chemical Research and Development Center, Aberdeen Proving Ground, MD.

Clean Air Act. 42 USC 7401-7671q. 40 CFR 53 et seq.

Clean Water Act. 33 USC 1251-1378. 40 CFR 401 et seq.

Coastal Zone Management Act. 16 USC 1451-1465.

Coggins, G.C., C.F. Wilkinson, and J.D. Leshy. 1993. Federal Public Land and Resources Law. Foundation Press, Westbury, NY.

Comprehensive Environmental Response, Compensation, and Liability Act. 42 CFR 9601-9657.

Conservation and Cultural Activities on Military Lands. 10 USC 2694.

Deliman, P.N., C.E. Ruiz, and J.A. Gerald. 2000. Summary Report, Risk Assessment Modeling Workshop. Final Report TR-00-6. U.S. Army ERDC-EL, Vicksburg, MS.

Deal, B.M., D.F. Fournier, D.M. Timlin, and E.M. Jenicek. 2002. An Assessment of Encroachment Mitigation Techniques for Army Lands. ERDC/CERL TR-02/27, ADA409139. U.S. Army ERDC/CERL, Champaign, IL.

Department of Defense Directive 4700.4, Natural Resources Management Program. Headquarters, Department of Defense, Washington, DC., 24 January 1989.

Department of Defense Directive 4715.1, Environmental Security. Headquarters, Department of Defense, Washington, DC. 24 February 1996.

Department of Defense Instruction 4715.3, Environmental Conservation Program. Headquarters, Department of Defense, Washington, DC. 3 May 1996. 
Driver, C.J., M.W. Ligotke, W.G. Landis, J.L. Downs, B.L. Tiller, E.B. Moore Jr., and D.A. Cataldo. 1993a. Environmental and Health Effects Review for Obscurant Graphite Flakes. ERDEC-CR-056. Final Report. Pacific Northwest Laboartory, Richland WA.

Driver, C.J., M.W. Ligotke, J.L. Downs, B.L. Tiller, T.M. Poston, E.B. Moore, Jr., and D.A. Cataldo. 1993b. Environmental and Health Effects Review for Obscurant Fog Oil. ERDEC-CR071. Final Report. U.S. Army Chemical and Biological Defense Agency, Edgewood Research, Development, and Engineering Center, Aberdeen Proving Ground, MD.

Driver, C., M. Ligotke, H. Galloway-Gorby, G. Dennis, K. Reinbold, and H. Balbach. 2002a. Acute Inhalation Toxicity of Fog Oil Smoke in the Red-winged Blackbird, a Size-specific Inhalation Surrogate for the Red-cockaded Woodpecker. ERDC/CERL TR-02-6, ADA399210. U.S. Army CERL, Champaign, IL.

Driver, C., J. Ollero, Y. F. Su, R. Fulton, G. Dennis, B. Tiller, H. Balbach, and K. Reinbold. 2002 b. Effects of Fog Oil Smoke on the Hatchability and Fledgling Survival in the House Sparrow (Passer domesticus), a Nestling Surrogate for the Red-cockaded Woodpecker. ERDC/CERL TR-02-34, ADA411029. U.S. Army CERL, Champaign, IL.

Driver, C., A. Jarrell, J. Ollero, B. Tiller, R. Fulton, G. Dennis, and K. Reinbold. In review. "Effects of Fog Oil Smoke on Immune Responses in the House Sparrow (Passer domesticus) and Red-winged Blackbird (Agelaius phoeniceus)." ERDC/CERL report. U.S. Army CERL, Champaign, IL.

Endangered Species Act. 16 USC 1531-1544. 50 CFR 402 et seq.

Federal Register 59-34275, July 1, 1994. Endangered and Threatened Wildlife and Plants: Notice of Interagency Cooperative Policy Regarding the Role of State Agencies in Endangered Species Act Activities.

Fish and Wildlife Coordination Act. 16 USC 661-667.

Gehlhausen, S., and M.G. Harper. 1998. Management of Maritime Communities for Threatened and Endangered Species. Technical Report 98/79, ADA350548. U.S. Army CERL, Champaign, IL.

Getz, L.L., K.A. Reinbold, D.J. Tazik, T.J. Hayden, and D.M. Cassels. 1996. Preliminary Assessment of the Potential Impact of Fog-Oil Smoke on Selected Threatened and Endangered Species. Technical Report 96/38, ADA306219. U.S. Army CERL, Champaign, IL.

Green, R.H. 1979. Sampling Design and Statistical Methods for Environmental Biologists. John Wiley and Sons, New York.

Grose, E.C., M.J. Selgrade, and D.W. Davis. 1986. Inhalation Toxicology of Fog Oil Smoke. Final Report ADA176109. U.S. Environmental Protection Agency, Washington, DC.

Guelta, M.A., and R.T. Checkai. 1995. Predictive Ecological Risk Assessment of Graphite Infrared Wavelength Obscurant in a Terrestrial Environment. ERDEC-TR-240. U.S. Army ERDEC, Aberdeen Proving Ground, MD. 
Hancox, R.J. 1989. A Review of the Physiological and Environmental Effects from the Dissemination of Metal Flake Obscurants. AD-B 138 539. Technical Report. Materials Research Laboratory, Victoria, Australia.

Hoffman, D.J., B.A. Rattner, G.A. Burton, Jr., and J. Cairns, Jr. 1995. Handbook of Ecotoxicology. Lewis Publishers, Boca Raton, FL.

Kachigan, S.K. 1986. Statistical Analysis: An Interdisciplinary Introduction to Univariate \& Multivariate Methods. Radius Press, New York.

Katz, S., A. Snelson, R. Butler, R. Farlow, R. Welker, and S. Mainer. 1980. Physical and Chemical Characteristics of Military Smokes - Part II Fog Oils and Oil Fogs. Contract No. DAMD17-78-C-8085. Final Report. U.S. Army Medical Research and Development Command, Ft. Detrick, Frederick, MD.

Keith, L.H. 1991. Environmental Sampling and Analysis: A Practical Guide. Lewis Publishers, Chelsea, MD.

Keller, W.C., R.G. Elves, and J.C. Bonnin. 1986. Assessment of CS Environmental Toxicity at Eglin AFB FL. USAFOEHL Report 86-058E00058HTB. Final Report. USAF Occupational and Environmental Health Laboratory, Brooks AFB, TX.

Klaassen, C.D., M.O. Amdur, and J. Doull. 1986. Casarett and Doull's Toxicology, the Basic Science of Poisons (3 ${ }^{\text {rd }}$ edition). Macmillan Publishing Co., NY.

Krysik, A.J. 1998. "Ecological Design and Analysis: Principles and Issues in Environmental Monitoring," pp 385-403 in Lanno, M.J. ed. Status and Conservation of Midwestern Amphibians. Univ. Iowa Press, Iowa City, IA.

Liljegren, J.C., W.E. Dunn, G.E. DeVaull, and A.J. Policastro. 1989. The Atterbury-87 Field Study of Smoke Dispersion and a New Stochastic Dispersion Model. U.S. Army MRDC, Fort Detrick, MD.

Lozar, R.C. 2002. Web Interface for Modeling Fog Oil Dispersion During Training. ERDC/CERL TR-02-16, ADA406751. U.S. Army CERL, Champaign, IL.

Lozar, R.C., and M.J. Hanson. 1997. "Dispersion Model and GIS Comparison/Evaluation in Support of TES Smokes and Obscurant Impacts.” Internal Report, 20 January. U.S. Army CERL, Champaign, IL.

Migratory Bird Treaty Act. 16 USC 703-712. 50 CFR 10.

Marine Mammals Protection Act. 16 USC 1361-1421h.

Magnusen-Stevens Fishery Conservation Act. 16 USC 1801-1883.

Muhly, R.I. 1983. Programatic Life Cycle Environmental Assessment For Smokes/Obscurants: Fog Oil, Diesel Fuels and Polyethylene Glycol (PEG 200). U.S. Army Chemical Research and Development Center, Aberdeen Proving Ground, MD. 
Nam, S., M.E. Walsh, J. Day, and K.A. Reinbold. 1999. Methods for Field Studies of the Effects of Military Smokes, Obscurants, and Riot-control Agents on Threatened and Endangered Species. Volume 4: Chemical Analytical Methods. Technical Report 99/56. ADA368051 paa. U.S. Army CERL, Champaign, IL.

National Defense Authorization Act for Fiscal Year 2003. PL 107-314.

National Environmental Policy Act. 42 USC 4321-4370. 40 CFR 1500-1508.

Palmer, W.G. 1990. Exposure Standard for Fog Oil. Technical Report 9010. U.S. Army MBRDL, Fort Detrick, MD.

Policastro, A.J., D.M. Maloney, W.E. Dunn, J.C. Liljegren, and G.E. DeVaull. 1989a. Evaluation of Atmospheric Dispersion Models for Fog-Oil Smoke Dispersion. U.S. Army MRDC, Fort Detrick, MD.

Policastro, A.J., D.M. Maloney, W.E. Dunn, J.C. Liljegren, and G.E. DeVaull. 1989b. Field Measurement and Model Evaluation Program for Assessment of the Environmental Effects of Military Smokes. Annual Report. Contract 84PP4822. U.S. Army Biomedical Research and Development Laboratory, Fort Detrick, Frederick, MD.

Rand, G.M., ed. 1995. Fundamentals of Aquatic Toxicology: Effects, Environmental Fate, and Risk Assessment. Taylor and Francis, Washington, DC.

Sample, B.E., T.L. Ashwood, B.A. Carrico, L.A. Kszos, M.S. Nazerias, T.L. Phipps, W.K. Roy, M.G. Ryon, E.M. Schilling, M. Smith, A.J. Stewart, G.W. Suter II, L.F. Wicker, and K.A. Reinbold. 1997. Methods for Field Studies of the Effects of Military Smokes, Obscurants, and Riot-Control Agents on Threatened and Endangered Species. Volume 2: Methods for Assessing Ecological Risks. Technical Report 97/140. U.S. Army CERL, Champaign, IL.

Sandusky, M.C. 1992. Guide for Collecting, Handling, and Preserving Soil Samples for the Analysis of Chemical Agents. Technical Report CRDEC-CR-143. U.S. Army, Aberdeen Proving Ground, MD.

Schaeffer, D.J., W.R. Lower, S. Kapila, A.F. Yanders, R. Wang, and E.W. Novak. 1986. Preliminary Study of Effects of Military Obscurant Smokes on Flora and Fauna During Field and Laboratory Exposure. Technical Report N-86/22, ADA176328. U.S. Army CERL, Champaign, IL.

Schaeffer, D.J., E.W. Novak, W.R. Lower, A. Yanders, S. Kapila, and R. Wang. 1987. "Effects of Chemical Smokes on Flora and Fauna Under Field and Laboratory Exposures." Ecotoxicol. and Env. Safety 13(301-315).

Schreiber, E. R., R.A. Shaw, A. Hill, and M.A. Reed. 1997. Installation Summaries From the 1996 Survey of Threatened and Endangered Species on Army Lands. USACERL Technical Report 98/19, ADA336407. U.S. Army CERL, Champaign, IL.

Schreiber, E. and M.A. Reed. 1999. Installation Summaries From the 1998 Survey of Threatened and Endangered Species on Army Lands. CERL Technical Report 99/78, ADA369718. U.S. Army CERL, Champaign, IL. 
Sendelbach, L.E. 1989. "A Review of the Toxicity and Carcinogenicity of Anthraquinone Derivatives." Toxicology 57:227-240.

Shaw, R.A., and A. Hill. 1996. Army-wide Threatened and Endangered Species Survey. USACERL Technical Note 96-101, ADA331941. U.S. Army CERL, Champaign, IL.

Shaw, R.A., E.R. Schreiber, A. Hill, and M.A. Reed. 1998. Installation Summaries From the 1997 Survey of Threatened and Endangered Species on Army Lands. USACERL Technical Report 98/106, ADA352526. U.S. Army CERL, Champaign, IL.

Shinn, J.H., L. Sharmer, M. Novo, and L.F. Katz. 1987a. Smokes and Obscurants: A Guidebook of Environmental Assessment, Volume I, Method of Assessment and Appended Data. U.S. Army, MRDC, Fort Detrick, MD.

Shinn, J.H., L. Sharmer, and M. Novo. 1987b. Smokes and Obscurants: A Guidebook of Environmental Assessment, Volume II, A Sample Environmental Assessment. ADA 203909. U.S. Army MRDC, Fort Detrick, MD.

Shore, R.F., and B.A. Rattner, eds. 2001. Ecotoxicology of Wild Mammals. John Wiley and Sons, New York.

Sikes Act. 16 USC 670 et seq.

Simini, M. 1992. Guide for Collecting, Handling, and Preserving Vegetation Samples for the Analysis of Chemical Agents. Technical Report CRDEC-CR-148. U.S. Army, Aberdeen Proving Ground, MD.

Snedecor, G.W. and W.G. Cochran. 1989. Statistical Methods. Iowa State Univ. Press, Ames, IA.

Sokal, R.R. and F.J. Rohlf. 1995. Biometry: The Principles and Practice of Statistics in Biological Research. W.H. Freeman and Co., New York.

Sustainable Fisheries Act Amendments. PL 104-297.

Suter, G.W. 1993. Ecological Risk Assessment. Lewis Publishers, Boca Raton, FL.

Suter, G.W. 1999. "Developing Conceptual Models for Complex Ecological Risk Assessments." Hum. Ecol. Risk Assess. 5(2):375-396.

Suter, G.W., R.M. Efroymson, B.E. Sample, and D.S. Jones. 2000. Ecological Risk Assessment for Contaminated Sites. Lewis Publishers, Boca Raton, FL.

Suter, G.W., K.A. Reinbold, W.H. Rose, and M.K. Chawla. 2001. "Military Ecological Risk Assessment Framework (MERAF) for Assessment of Risks of Military Training and Testing to Natural Resources.” Unpublished Final Report. U.S. Army CERL, Champaign, IL.

Trame, A., and D.J. Tazik. 1995. The Implications of Ecosystem Management for Threatened and Endangered Species Conservation by the U.S. Army. Technical Report 95/27, ADA302406. U.S. Army CERL, Champaign, IL. 
Tazik, D.J. and P. Pierce. 1994. In Tazik, D.J., C. Martin, P. Pierce, and J. Ruth, eds. Proceedings - Interagency Endangered Species Symposium. Special Report EN 94/08, ADA286346. U.S. Army CERL, Champaign, IL.

U.S. Air Force Instruction 32-7064, Integrated Natural Resources Management. Headquarters, U.S. Air Force, Washington, DC., 1 August 1997.

U.S. Air Force. 1999. Environmental Impact Analysis Process. 32 CFR 989, incorporated in AFI 32-7061.

U.S. Army. 1988. Environmental Effects of Army Actions. 32 CFR 651, incorporated in AR 200-2.

U.S. Army. 1996. Biological Assessment of the Master Plan and Ongoing Mission. Appendix II. Effect of Certain Aerosol Contaminants on Indiana Bats and Gray Bats at Fort Leonard Wood. U.S. Army Engineer Center and Fort Leonard Wood, MO.

U.S. Army. 2001. U.S. Army Environmental Requirements and Technology Assessments (AERTA). SFIM-AEC-ET-CR-200136. U.S. Army Environmental Center, Aberdeen, MD.

U.S. Army. 2002. Environmental Technology Management Plan - Conservation. U.S. Army CERL, Champaign, IL.

U.S. Army Regulation 200-3, Natural Resources - Land, Forest and Wildlife Management. Headquarters, U.S. Army, Washington, DC., 28 February 1995.

U.S. Environmental Protection Agency. 1983. Methods for Chemical Analysis of Water and Wastes. EPA-600/4-79-020. Environmental Monitoring and Support Laboratory, Office of Research and Development, Cincinnati, $\mathrm{OH}$.

U.S. Environmental Protection Agency. 1988. Compendium of Methods for the Determination of Toxic Organic Compounds in Ambient Air. EPA-600/4-89-017. Quality Assurance Division of Environmental Monitoring Systems Laboratory, Office of Research and Development, Research Triangle Park, NC.

U.S. Environmental Protection Agency. 1989a. Risk Assessment Guidance for Superfund, Volume I: Environmental Evaluation Manual. OSWER Directive 9285.701. EPA 540/1-89/002. Washington, DC.

U.S. Environmental Protection Agency. 1989b. Risk Assessment Guidance for Superfund, Volume II: Environmental Evaluation Manual. EPA/540-1-89/001. Washington, DC.

U.S. Environmental Protection Agency. 1991a. Methods for the Determination of Organic Compounds in Drinking Water. EPA-600/4-88/039, EPA-600/4-90/020 (Supplement 1) and EPA-600/R-92/129 (Supplement 2). Environmental Systems Laboratory, Office of Research and Development, Cincinnati, $\mathrm{OH}$.

U.S. Environmental Protection Agency. 1991b. Methods for the Determination of Metals in Environmental Samples. EPA-600/4-91/010 and EPA-600/R-94/111 (Supplement 1). Environmental Monitoring Systems Laboratory, Office of Research and Development, Cincinnati, $\mathrm{OH}$. 
U.S. Environmental Protection Agency. 1992. Framework for Ecological Risk Assessment. Risk Assessment Forum. EPA/630/R-92/001. Washington, DC.

U.S. Environmental Protection Agency. 1993a. Methods for the Determination of Inorganic Substances in Environmental Samples. EPA-600/R-93/100. Environmental Monitoring Systems Laboratory, Office of Research and Development, Cincinnati, OH.

U.S. Environmental Protection Agency. 1993b. Wildlife Exposure Factors Handbook, Volumes I and II. EPA/600/R-93/187a and b. Washington, DC.

U.S. Environmental Protection Agency. 1995. Test Methods for Evaluating Solid Waste. EPA SW-846. Office of Solid Waste and Emergency Response, Washington, DC.

U.S. Environmental Protection Agency. 1998. Guidelines for Ecological Risk Assessment. Risk Assessment Forum. EPA/630/R-95/002F. Washington, DC.

U.S. Marine Corps Order P5090.2A, Environmental Compliance and Protection Manual. Headquarters, U.S. Marine Corps, Washington, DC., 10 July 1998.

U.S. Navy Instruction OPNAVINST 5090.1B, Navy Environmental and Natural Resources Program Manual. Headquarters, U.S. Navy, Washington, DC., 9 September 1999.

U.S. Supreme Court. 1976. Kleppe v. New Mexico, 426 US 529.

Walker, T.L. 2002. Technical Document for Ecological Risk Assessment: Planning for Data Collection. SFIM-AEC-ER-TR-2002017. U.S. Army Biological Technical Assistance Group, Aberdeen Proving Ground, MD.

Wentsel, R.S. 1986. Fate and Effects of Brass Powder on the Environment. ADB 104703. U.S. Army CRDEC, CBDC, Aberdeen Proving Ground, MD.

Wentsel, R.S. and M.A. Guelta. 1986. The Fate of Brass Powder in the Soil. PO 84PP4804 Technical Report. U.S. Army Chemical Research Development and Engineering Center, Aberdeen Proving Ground, MD.

Wentsel, R.S., T.W. LaPoint, M. Simini, R.T. Checkai, D. Ludwig, and L.W. Brewer. 1996. Triservice Procedural Guidelines for Ecological Risk Assessments. 19960924 088. U.S. Army ERDEC, Aberdeen Proving Ground, MD.

Whelan, G., J.W. Buck, G.M. Gelston, and K.J. Castleton. 1999. Framework For Risk Analysis in Multimedia Environmental Systems - Training Manual. Pacific Northwest National Laboratory, Richland, WA.

Whitworth, M. 1994. In Tazik, D.J., C. Martin, P. Pierce, and J. Ruth, eds. Proceedings Interagency Endangered Species Symposium. Special Report EN-94/08, ADA286346. U.S. Army CERL, Champaign, IL.

Zar, J.H. 1999. Biostatistical Analysis. Prentice Hall, Upper Saddle River, NJ. 


\section{Appendix: Acronyms and Abbreviations}

\begin{tabular}{|c|c|}
\hline AFI & Air Force Instruction \\
\hline $\mathrm{AR}$ & Army Regulation \\
\hline CAA & Clean Air Act \\
\hline CFR & Code of Federal Regulations \\
\hline $\mathrm{COE}$ & Corps of Engineers \\
\hline CS & o-chlorobenzalmalononitrile \\
\hline CWA & Clean Water Act \\
\hline CZMA & Coastal Zone Management Act \\
\hline DoD & Department of Defense \\
\hline DoDD & Department of Defense Directive \\
\hline DoDI & Department of Defense Instruction \\
\hline EPA & Environmental Protection Agency \\
\hline ESA & Endangered Species Act \\
\hline ESMP & Endangered Species Management Plan \\
\hline FWMP & Fish and Wildlife Management Plan \\
\hline FWCA & Fish and Wildlife Coordination Act \\
\hline FWS & Fish and Wildlife Service \\
\hline $\mathrm{HC}$ & hexachloroethene (smoke) \\
\hline INRMP & Integrated Natural Resources Management Plan \\
\hline MBTA & Migratory Bird Treaty Act \\
\hline $\mathrm{MCO}$ & Marine Corps Order \\
\hline
\end{tabular}


MSFCMA Magnusen-Stevens Fishery Conservation and Management Act

MMPA Marine Mammals Protection Act

NEPA National Environmental Policy Act

NMFS National Marine Fisheries Service

OPNAVINST Office of the Chief of Naval Operations Instruction

SERDP Strategic Environmental Research and Development Program

SEMP SERDP Ecosystem Management Project

USC U.S. Code

WP white phosphorous (smoke) 


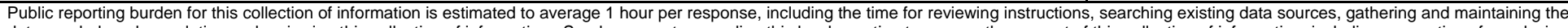

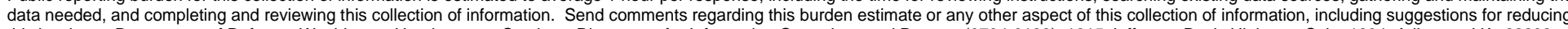

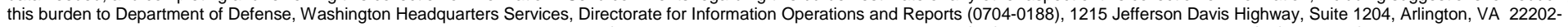

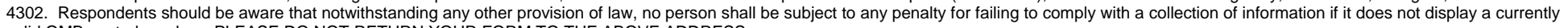
valid OMB control number. PLEASE DO NOT RETURN YOUR FORM TO THE ABOVE ADDRESS.
1. REPORT DATE (DD-MM-YYYY)
2. REPORT TYPE
3. DATES COVERED (From - To)

04-2004

Final

\section{TITLE AND SUBTITLE}

Methods for Field Studies of the Effects of Military Smokes, Obscurants, and Riot-control

Agents on Threatened and Endangered Species:

Volume 1: Background, Overview, Issues, and Recommendations

6. AUTHOR(S)

Thomas Smith

\section{PERFORMING ORGANIZATION NAME(S) AND ADDRESS(ES)}

U.S. Army Engineer Research and Development Center (ERDC)

Construction Engineering Research Laboratory (CERL)

5a. CONTRACT NUMBER

PO Box 9005

Champaign, IL 61826-9005

\section{SPONSORING I MONITORING AGENCY NAME(S) AND ADDRESS(ES)}

Strategic Environmental Research and

\section{SPONSOR/MONITOR'S ACRONYM(S)}

Development Program

901 N. Stuart St.

Arlington, VA 22203-1821

5b. GRANT NUMBER

5c. PROGRAM ELEMENT NUMBER

\section{5d. PROJECT NUMBER}

SERDP

5e. TASK NUMBER

CS-766

5f. WORK UNIT NUMBER

8. PERFORMING ORGANIZATION REPORT

NUMBER

ERDC/CERL TR-04-5

\section{DISTRIBUTION I AVAILABILITY STATEMENT}

Approved for public release; distribution is unlimited.

\section{SUPPLEMENTARY NOTES}

Copies are available from the National Technical Information Service, 5285 Port Royal Road, Springfield, VA 22161.

\section{ABSTRACT}

Smokes, obscurants, and riot-control agents constitute a diverse group of chemical compounds that are released into the environment during training exercises. Concern has been expressed over the use of these compounds and how they may affect threatened and endangered (T\&E) species that reside on military installations.

This report (Volume 1 in a series) contains an overview of studies and investigations on the effects and impacts of military smokes, obscurants, and riot-control agents on T\&E species. It also discusses the primary laws and regulations of interest and importance to the military services when using these agents on training lands.

Volume 2 (CERL TR 97/140, September 1997) reviews methods for assessing ecological risks. Volume 3 (ERDC/CERL TR-01-59, September 2001) discusses strategies for developing a statistically sound approach to assessing the effects of military smokes, obscurants, and riot-control agents. Volume 4 (USACERL Technical Report 99/56, July 1999) examines chemical analytical methods for isolating and detecting the components of smokes, obscurants, and riot-control agents from environmental media.

\section{SUBJECT TERMS}

smoke, threatened and endangered species, ecosystem management, obscurants, military training, Strategic Environmental Research and Development Program (SERDP)

\begin{tabular}{|c|c|c|c|c|}
\hline \multicolumn{3}{|c|}{ 16. SECURITY CLASSIFICATION OF: } & \multirow{2}{*}{$\begin{array}{l}\text { 17. LIMITATION } \\
\text { OF ABSTRACT } \\
\text { SAR }\end{array}$} & \multirow{2}{*}{$\begin{array}{l}\text { 18. NUMBER } \\
\text { OF PAGES } \\
50\end{array}$} \\
\hline $\begin{array}{l}\text { a. REPORT } \\
\text { Unclassified }\end{array}$ & $\begin{array}{l}\text { b. ABSTRACT } \\
\text { Unclassified }\end{array}$ & $\begin{array}{l}\text { c. THIS PAGE } \\
\text { Unclassified }\end{array}$ & & \\
\hline
\end{tabular}

19a. NAME OF RESPONSIBLE PERSON Thomas Smith

19b. TELEPHONE NUMBER (include area code)

(217) 352-6511, ext 7414 